\title{
IMPACT OF EDUCATION AND ECONOMIC GROWTH ON LABOUR MIGRATION IN THE EUROPEAN UNION. A PANEL DATA ANALYSIS
}

\author{
Nicolae Istudor', Vasile Dinu², Emilia Gogu³, \\ Elena-Maria Prada ${ }^{4}$, Irina-Elena Petrescu ${ }^{5}$
}

1 Bucharest University of Economic Studies, Faculty of Agro-Food and Environmental Economics, Department of Agro-Food and Environmental Economics, Romania, ORCID: 0000-0002-4581-4548, nicolae.istudor@ase.ro;

2 Bucharest University of Economic Studies, Faculty of Business and Tourism, Department of Business, Consumer Science and Quality Management, Romania, ORCID: 0000-0003-3606-2548, dinu_cbz@yahoo.com;

3 Bucharest University of Economic Studies, Faculty of Economic Cybernetics, Statistics and Informatics, Department of Statistics and Econometrics, Romania, ORCID: 0000-0002-7333-7128, arina_emilia@yahoo.com;

4 Bucharest University of Economic Studies, Faculty of Economic Cybernetics, Statistics and Informatics, Department of Statistics and Econometrics, Romania, ORCID: 0000-0001-7215-3207, elena.prada@csie.ase.ro;

5 Bucharest University of Economic Studies, Faculty of Agro-Food and Environmental Economics, Department of Agro-Food and Environmental Economics, Romania, ORCID: 0000-0002-7549-790X, irina.petrescu@ase.ro.

\begin{abstract}
Since migration is considered to play an important role on the attainment of the sustainable development goals (SDG's) this study analyses the reversed perspective of the migration-SDG's nexus. The data set consists of 308 observations on 28 European Union countries (including the United Kingdom) over a time span of 11 years (between 2008 and 2018).

The analysis employed various stages of estimation in order to compare different results obtained from the panel data regression models. Besides the classical panel data regression models, the paper includes the estimation of Arellano-Bover/Blundell-Bond model that uses the Generalized Method of Moments (also known as GMM) as an econometric tool to solve the endogeneity of the selected variables.

The focus is on two sustainable development goals: labour and economic growth, and education of the European Union member states plus the United Kingdom. The results showed that there is a significant influence of the selected variables on the migration flows at the European Union level. Although there are some contradictory results regarding the direction and statistical significance of the link between the variables of interest, most estimators do not have fundamentally different results. The GDP per capita keeps its positive impact on migration by generating an immigration flow towards countries with high GDP per capita. Economic growth proves to be the main trigger of migration, while education also plays an important role in shaping migration. The importance of this study derives from the reversed perspectives analysis, considering migration as being directly influenced by the achievement of the sustainable development goals.
\end{abstract}

Keywords: Labour migration, sustainable development goals, quality education, decent work and economic growth, panel data, dynamic GMM.

JEL Classification: C23, F22, O15, Q01.

APA Style Citation: Istudor, N., Dinu, V., Gogu, E., Prada, E.-M., \& Petrescu, I.-E. (2020). Impact of Education and Economic Growth on Labour Migration in the European Union. A Panel Data Analysis. E\&M Economics and Management, 23(4), 55-67. https://doi.org/10.15240/ tul/001/2020-4-004 


\section{Introduction}

The migration phenomenon is complex and difficult to fully understand and summarize. From the perspective of human migration there are numerous studies that have tried to systematize the reasons of migration (Parkins, 2011; Faist, 2011; O'Reilly, 2013; Wickramasinghe \& Wimalaratana, 2016). One of the main components of migration is labour migration. Most studies have dedicated an important part of literature to labour migration and many of the migrationist theories have revolved around this aspect: neo-classical theory, New Economics of Labour Migration (also known as NELM), Dual Labour Market Theory (Wickramasinghe \& Wimalaratana, 2016).

This paper explores the determinants of migration from the perspective of the sustainable development goals (SDG's) that are related to education, decent work and economic growth.

Migration plays an important role in achieving the SDG's. Most studies consider migration as a variable that influences the achievement of SGD's, usually as being an element of destabilization of the initial development trajectory (Bali Swain \& Yang-Wallentin, 2020; Holliday et al., 2019; International Organization for Migration, 2018; Overseas Development Institute, 2017), but what if there is a bilateral relationship between migration flows and achievement of sustainable development? Not only that migration can be a key cause in reaching the sustainable development (Overseas Development Institute, 2017), but at the same time reaching the Sustainable Development Goals can become a push or pull factor for migrants. Therefore, can the achievement of the SDG's encourage the labour migration?

In order to answer this questions, the main focus of the analysis is to show whether migratory flows are influenced by the fulfilment of two SDGs: SDG 4 - Quality education and SDG 8 - Decent work and economic growth. The choice of these SDGs had as a starting point results from the main migrationist theories. The variables employed in the analysis are the migration - SDG's related indicators according to the Eurostat database. Some data retrieving issues, as the presence of missing values for some of the variables of interest led to the following variables employed in the analysis:

- SDG 4: Tertiary Education Total, Employment rates of Recent Graduates and Adult participation in Learning;
- SDG 8: GDP per Capita, Unemployment Total, Young people neither in employment nor in education and training by sex (NEET) and GINI coefficient.

This research contributes to the current literature from two perspectives: it enriches the current studies related to SDG and migration using panel data analysis, and it has high significance for the educational and labour policymakers. Another purpose of this paper is to compare the statistical results obtained from different panel data estimated models. Results showed there is a significant influence of the education and economic growth on migration flows.

The paper is structured on four sections. The first section focuses on a brief description of SDG's history and the literature review of the main studies that have analysed the relationship between migration and sustainable development. The second section introduces the methodology and the data retrieving issues. Section three is dedicated to the empirical results. Finally, the last section concludes the results and raises the issue of the actual COVID-19 crisis and how it might change the migration patterns.

\section{Theoretical Background and Literature Review}

The Sustainable Development Goals were firstly established in 1992 through the Agenda 21, at the United Nations Conference on Environment and Development that took place in Rio de Janeiro, Brazil, where 21 targets, called The Millennium Development Goals (MDG), were set to be achieved by 2015 (Sitarz, 1993). The MDG's contained eight specific goals related to heath, environment, poverty, education, gender equality (with an emphasis on woman empowerment) (United Nations, 2005; Hulme, 2009).

The main limitations of MDG's were mostly related to the fact that these were considered unrealistic and far too ambitious, but also too few to achieve sustainable development. Some authors argued the lack of interconnectivity between goals, for example: the maternity care and child mortality were considered two separated goals (Fehling et al., 2013; Death \& Gabay, 2015).

Most authors considered that the achievement of MDG's has led to mixed results (Sachs \& McArthur, 2005; Sachs, 2012; Death 
\& Gabay, 2015; Kumar et al., 2016) and as consequence in 2015, a new set of 17 goals, called Sustainable Development Goals, was established through the Agenda 2030: No poverty; Zero hunger; Good health and wellbeing; Quality education; Gender equality; Clean water and sanitation; Affordable and clean energy; Decent work and economic growth; Industry, innovation, and infrastructure; Reduce inequality; Sustainable cities and communities; Responsible consumption and production; Climate action; Life under water; Life on land; Peace, justice, and strong institutions and Partnership for the goals (Kumar et al., 2016).

Migration and sustainable development has gained increasing importance after the Sustainable Development Goals were developed. Though there are some studies that analyse the relationship between Millennium Development Goals and migration (Usher, 2005; Skeldon, 2008; McGregor, 2020), once the SDG's were developed it became an important chapter of analysis. Based on the achievements of their predecessors, MDG's, the SDG's included a target related to "well-governed migration": SDG Target 10.7 - facilitate orderly, safe, and responsible migration and mobility of people, including through implementation of planned and well-managed migration policies (International Organization of Migration, 2019).

According to the Global Forum on Migration and Development (2017), the member states of International Organization of Migration (IOM) developed in 2015 the Migration Governance Framework (MiGOF). This framework has as an operationalization tool the Migration Governance Indicators (MGI). The MGI's can help identify the disparities between countries with respect to migration policies, and also, the countries can measure their progress for achieving a better migration governance (International Organization of Migration, 2019).

Though the MGl's are strictly related to Reduce Inequality within and among countries (International Organization of Migration, 2019), this paper focuses on SDG 4 - Quality education and SDG 8 - Decent work and economic growth, based on the main migration determinants (Mayda, 2010; Faist, 2011; Haas, 2011).

Education, decent work and economic growth are strongly interconnected. Firstly, education is an important process to imparting and creating knowledge and skills. Secondly, labour market is positively influenced by economic growth. According to a recent study at European Union level, if the Gross Domestic Product increases, a diminishment of the unemployment rate can be expected (Soylu et al., 2018). According to Nicolai et al. (2016), education also helps people to integrate in into the society and culture of their host country.

The literature regarding migration and sustainable development goals is scarce. Though some authors have studied the migrationdevelopment nexus (Nyberg-Sørensen et al., 2002), the subject of sustainable development and migration was poorly approached. Most studies consider migration as being a factor that influences SDG's (Piper, 2017; Long et al., 2017). Hence, SDG's can act as pull or push factors for migration.

\section{Research Methodology and Data Retrievement}

This paper examines, from the perspective of sustainable development, how education and economic growth of a country influence the migration flows by means of panel data models. Panel data has the advantage of using two dimensions: cross-sectional and time. These two dimensions can be analysed altogether or by highlighting if the influences of the dependent variables are due to the variation over time or due to the cross-sectional variation.

In order to compare the results of different estimations based on the retrieved data, this article employs the estimation of the following panel data models (Wooldridge, 2010):

- pooled panel data regression, which represents in fact the estimation of the classical linear regression model, and which pools the data altogether, regardless of the variations across cross-sectional dimension (also called the variation between) and across time dimension (also known as variation within);

- fixed effects model, which underlines the variation of the variables over time, taking into consideration the variation within;

- random effects model underlines the variation of the variables over individuals (in this study over countries) by taking into consideration the variation between;

- system generalized method of moments (Dynamic GMM), also known as ArellanoBover/Blundell-Bond linear dynamic panel-data estimation, which is designed 
for datasets with few time observations and helps controlling the endogeneity of the selected variables (Roodman, 2009; Napolitano \& Bonasia, 2010; StataCorp, 2015; Ullah et al., 2018; Ahmad \& Khan, 2019).

Panel data models are often applied to study the migration determinants (Napolitano \& Bonasia, 2010; Mayda, 2010; Haas, 2011; Etzo, 2011; Ha et al., 2016; Franc et al., 2019). Considering the focus of this article, panel data models can be applied to analyse whether the variables associated with the $4^{\text {th }}$ and the $8^{\text {th }}$ sustainable development goals determine the migration flows across European Union.

The classical panel data model, for estimating pooled regressions and fixed and random effects models, is described by the following linear equation (Hsiao, 2014):

$$
y_{j, t}=\alpha_{0 j}+\sum_{i=1}^{k} x_{i j, t} \cdot \beta_{i, j}+\varepsilon_{j, t}
$$

To control the endogeneity that may occur within the observed variables, most authors suggest the estimation of dynamic or system generalized method of moments (Teixeira \& Queirós, 2016).

The system generalized method of moments is also known as the Arellano-Bover/BlundellBond linear dynamic panel-data estimation and is described as a function of lagged endogenous variable (Hausman \& Pinkovskiy, 2017):

$$
y_{j, t}=\alpha_{0 j} \cdot y_{i, t-1}+\sum_{i=1}^{k} x_{i j, t} \cdot \beta_{i j}+\varepsilon_{j, t}
$$

where:

$\boldsymbol{y}_{j \boldsymbol{t}}$ represents the endogenous variable for country $j(j=1, \ldots, N, N)$ and year $t(t=1, \ldots$, T, T);

$\boldsymbol{x}_{i j t}$ represents the exogenous variable $i(i=1$, $\ldots, k)$ for country $j$ and year $t(t=1, \ldots, T, T)$;

$\boldsymbol{\alpha}_{0}$ represents the intercept which is common for all $j$ countries;

$\varepsilon_{j t}$ represents the error term which is independently and identical distributed with mean zero and continuous variation.

Arellano-Bover/Blundell-Bond is an estimator designed for typical situations as:

- the data set contains few time observations and a large number of cross-sectional observations;

- the endogenous variable has a dynamic character and is influenced by its past values;
- the variables may be subject to endogeneity;

- the model may be affected by the presence of heteroscedasticity and autocorrelation within cross-sectional observations (Baum, 2014).

The data set consists of 28 European Union countries, including the United Kingdom before the Brexit, over the period between 2008 and 2018.

Also, for some key measurement indicators, the development of the methodology and the determination of the data sources are still an ongoing process (United Nations General Assembly, 2017). Consequently, the dataset covers a period of 11 years, and the variables of interest are presented in Tab. 1, together with a short description.

The endogenous variable employed in this analysis is the crude rate of net migration, which is a measurement of the migration flows within a country. According to Eurostat Metadata, this indicator is computed as net migration (emigration minus immigration) divided by the average population of a country in a specific year. A negative value of this rate shows that a specific country has a dominant immigration flow, while a positive value shows a dominant emigration flow. Fig. 1 presents the crude rate of migration distribution in 2018 at European Union level, except Malta which registered the highest crude rate of net migration (35.3), according to the Eurostat Database.

In 2018, the countries with a negative crude rate of migration were (in ascending order): Croatia (-3.3), Romania (-2.8), Latvia (-2.5), Lithuania $(-1.2)$, France $(-0.8)$ and Bulgaria $(-0.5)$.

In order to show the relationship between the crude rate migration and to compare results from different estimations, four stages of analysis have been performed in this article:

- the first stage estimated the first three classical panel data models (pooled, fixed effects and random effects) with no intervention on the observed variables regarding main assumptions (stationarity and heteroscedasticity);

- the second stage tested the presence of unit root (for the variables that presented the unit root was applied the first difference operator) and re-estimated the model using first difference operator;

- the third stage tested for the presence of heteroscedasticity and re-estimated the model from the second stage; 


\section{Tab. 1: Description of the exogenous variables}

\section{Variable}

Description

Goal 4: Ensure inclusive and equitable quality education and promote lifelong learning opportunities for all

\begin{tabular}{l} 
Tertiary education total \\
\hline Employment rates of recent \\
graduates
\end{tabular}

Adult participation in learning learning

Population with tertiary educational attainment level measures the share of the population aged 30-34 who have successfully completed tertiary studies: ISCED 2011 level 5-8 for data from 2014 onwards and to ISCED 1997 level 5-6 for data up to 2013.

Refers to the persons aged 20 to 34 that are fulfilling the following conditions: employed according to the International Labour Organization definition, have attained at least upper secondary education (ISCED 3) as the highest level of education and not having received any education or training in the four weeks preceding the survey and four, having successfully completed their highest educational attainment 1,2 or 3 years before the EU Labour Force Survey (EU-LFS).

The indicator measures the share of people aged 25 to 64 who stated that they received formal or non-formal education and training in the four weeks preceding the EU Labour Force Survey (EU-LFS) from the total population of the same age group (those who did not answer to the question "participation in education and training" were excluded). Adult learning refers to learning activities after the end of initial education and covers general and vocational formal and non-formal learning activities.

\begin{tabular}{l|l}
\hline \multicolumn{2}{c}{ Goal 8: Promote sustained, inclusive and sustainable economic growth, full and productive } \\
employment and decent work for all
\end{tabular}

Source: Eurostat Metadata

- the fourth stage estimated the model using the generalized method of moments due to fact that the dataset consisted of small $T$ observations and large $\mathrm{N}$ observations, and also because the variable included in model may have been affected by endogeneity. All the results were estimated with Stata.

\section{Research Results}

The Hausman test and the Breusch-Pagan Lagrange multiplier test were applied in the first stage of analysis in order to decide between the estimated models. All the variables of interest were involved, regardless of stationarity and homoscedasticity.

The final results of this stage show that random effects are the right approach. Random effects models show that the difference occurs across the entities. In case of the GDP per Capita, it can be observed that there is a positive and significant coefficient. This means that, if a specific country has a higher 


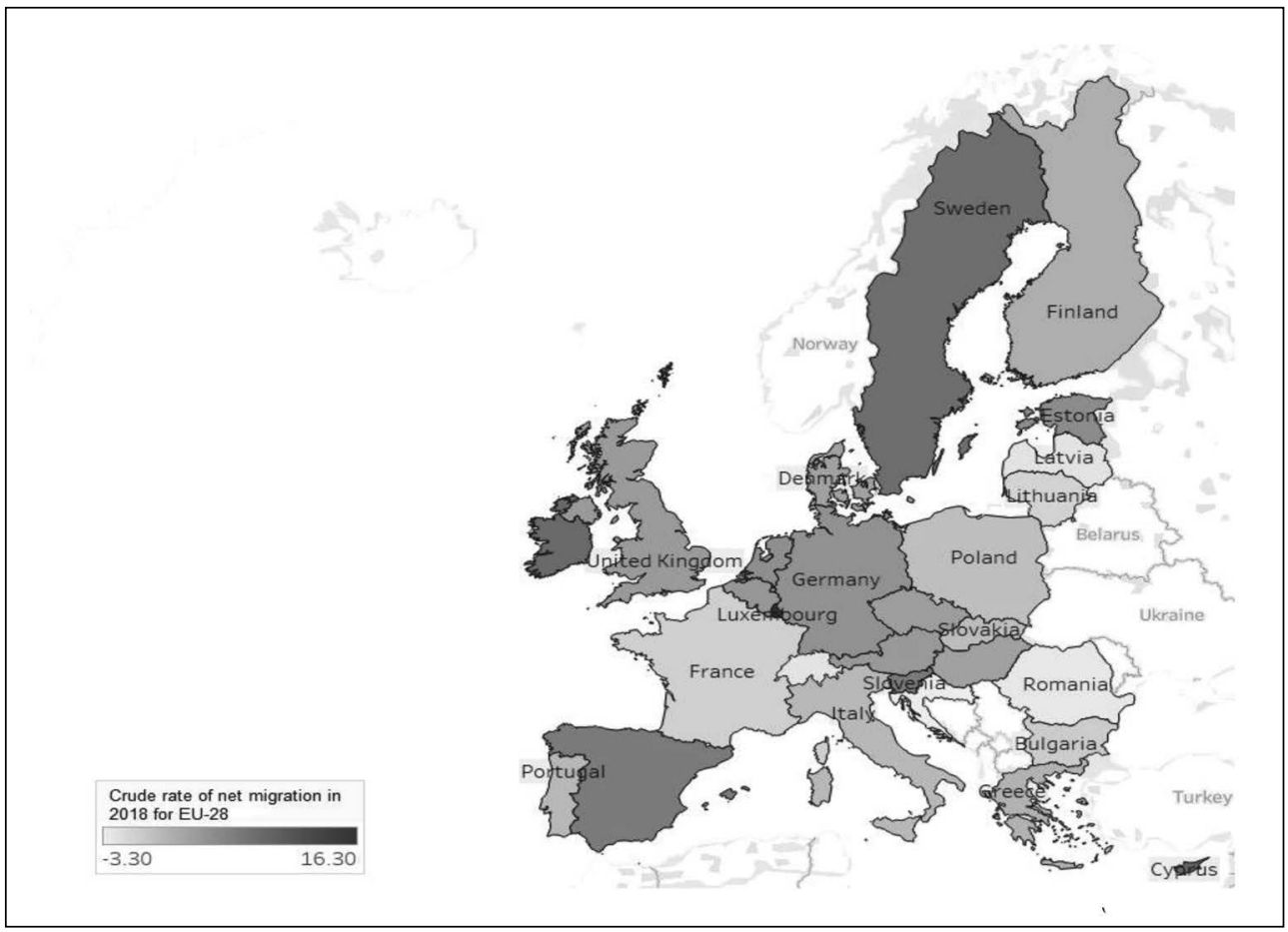

Source: own

GDP, the migration flow in that country is towards immigration. This result is in line with most findings of other researchers (Mayda, 2010; Etzo, 2011). The following variables have an inverse relationship with crude rate of net migration: Unemployment, Young people neither in employment nor in education and training by sex (NEET), GINI coefficient, Tertiary Education, Employment rates of Recent Graduates, Adult participation in Learning. This shows that, as these variables have higher values, the migration trend in that country is to emigrate.

An important aspect for the stationary analysis is to study the number of observations for each type of variation (See Tab. 1A in Appendix):

- Overall Variation is denoted with $\mathrm{N}=308(28 \times 11)$ and represents the total number observations;

- between variation corresponding to the number of countries included is denoted with $\mathrm{n}=28$;
- within variation corresponding to number of years included is denoted with $T=11$.

To diagnose the stationarity of the variables involved, the Harris-Tsavalis test was applied in the second stage of analysis.

Though there are multiple test used to study the presence of the panel data unit root (StataCorp, 2013), the Harris-Tsavalis test is suggested for panel data sets with small time observation and large cross-sectional observations (Harris \& Tzavalis, 1999).

Tab. 2 presents the results obtained for the variables in level and for the variables on which the first difference operator was applied. The null hypothesis of the test shows the presence of unit root if accepted. The test showed the presence of stationarity at a $5 \%$ significance level only for two variables in level: GINI coefficient and employment rate of recent graduates. After the first difference operator was applied, the Harris-Tsavalis test was used 


\begin{tabular}{c|c|c} 
& Rho (variable in level) & Rho (first difference) \\
\hline GDPperCapita & 0.8915 & $\mathbf{- 0 . 0 0 3 8 ^ { * }}$ \\
\hline NEET & 0.7274 & $\mathbf{0 . 3 3 6 7 ^ { * }}$ \\
\hline UnemploymentTotal & 0.7244 & $\mathbf{0 . 4 9 9 1 ^ { * }}$ \\
\hline TertiaryEducationalAttainment & 0.8757 & $\mathbf{- 0 . 1 9 1 3 ^ { * }}$ \\
\hline GINIcoeff & $\mathbf{0 . 6 1 9 8}^{*}$ & - \\
\hline EmploymentRateofRecentGraduates & $\mathbf{0 . 6 0 5 3 ^ { * }}$ & - \\
\hline AdultParticipationinLearning & 0.8313 & $\mathbf{- 0 . 0 6 4 7 ^ { * }}$ \\
\hline
\end{tabular}

Note: ${ }^{*}$-value $<0.05$.

\section{Tab. 3: Goodness of fit tests}

\begin{tabular}{l|c} 
Serial correlation & $F(1 ; 27)=19.264^{*}$ \\
\hline Heteroscedasticity (modified Wald test) & chi2 $(28)=1,888.60^{\star}$ \\
\hline
\end{tabular}

Source: own

Note: *P-value $<0.05$.

to verify if the presence of unit root still persists. The results obtained for the second stage must be reluctantly studied and interpreted since the time component significantly reduces the number of observations by applying the first difference operator.

Tab. 3 presents the results of the goodness of fit test regarding serial correlation and heteroscedasticity. In order to test for serial correlation, the Wooldridge test was applied. Though the probability of the test is significant and we can conclude that the model should be adjusted for serial correlation, according to Torres-Reyna (2007), serial correlation is not an issue for panel data with short time series (under 20 years).

To check for heteroscedasticity, the Modified Wald test for groupwise heteroscedasticity was used. The results showed that the null hypothesis is accepted and the presence of heteroscedasticity is confirmed. A way to correct for heteroscedasticity is to estimate the model with robust standard errors (StataCorp, 2015). The results of the estimated coefficients are presented in Tab. 4. As expected, there are no differences between the values of the coefficients estimated in stages 2 and 3 . A slight change is observed in the significance of the coefficients. Adult participation learning and GINI coefficient are significant at 10\% significance level. Also, the results regarding the overall significance of the models suggest that there is at least one exogenous variable that influences the crude rate of net migration (Wald - Chi-squared test is significant at $1 \%$ significance level). In case of random effects model the R-squared has a larger value for the variation between. This happens because the influence of the exogenous variables on crude rate of net migration is due to cross-sectional variation. Another important statistical result is Rho value. Considering the random effects model Rho refers to that part of the total variance which is due to the residual variable (Baum, 2006). Consequently, the variation of the cross-sectional effect is explained in proportion of $54.1 \%$, respectively $57.99 \%$ by the variation of the residual component.

The Arellano-Bover/Blundell-Bond model is also known as dynamic GMM and uses the generalized method of moments. To control for endogeneity, the Arellano-Bover/Blundell- 


\begin{tabular}{|c|c|c|c|c|}
\hline \multirow[b]{2}{*}{ CrudeRateofNetMigration } & Stage 1 & Stage 2 & Stage 3 & Stage 4 \\
\hline & RE & RE FD & $\begin{array}{c}\text { RE FD } \\
\text { (robust) }\end{array}$ & $\begin{array}{c}\text { Dynamic } \\
\text { GMM }\end{array}$ \\
\hline L.CrudeRateofNetMigration & - & - & - & $\begin{array}{c}0.573^{*} \\
{[0.000]}\end{array}$ \\
\hline GDPperCapita & $\begin{array}{c}0.064^{*} \\
{[0.000]}\end{array}$ & - & & - \\
\hline NEET & $\begin{array}{l}-0.700^{*} \\
{[0.002]}\end{array}$ & - & & - \\
\hline UnemploymentTotal & $\begin{array}{l}-0.747 \\
{[0.123]}\end{array}$ & - & & - \\
\hline TertiaryEducationalAttainment & $\begin{array}{c}0.069^{*} \\
{[0.017]}\end{array}$ & - & & - \\
\hline GINIcoeff & $\begin{array}{l}-0.357^{*} \\
{[0.000]}\end{array}$ & $\begin{array}{l}-0.511^{*} \\
{[0.003]} \\
\end{array}$ & $\begin{array}{l}-0.511 \\
{[0.095]} \\
\end{array}$ & $\begin{array}{l}-0.606^{*} \\
{[0.000]}\end{array}$ \\
\hline EmploymentRateofRecentGraduatues & $\begin{array}{l}-0.374 \\
{[0.494]}\end{array}$ & $\begin{array}{l}0.287^{*} \\
{[0.000]}\end{array}$ & $\begin{array}{l}0.287^{*} \\
{[0.001]}\end{array}$ & $\begin{array}{c}0.164^{*} \\
{[0.002]}\end{array}$ \\
\hline AdultparticipationinLearning & $\begin{array}{c}-0.062^{*} \\
{[0.000]}\end{array}$ & - & & - \\
\hline D.GDPperCapita & - & $\begin{array}{c}0.036 \\
{[0.652]}\end{array}$ & $\begin{array}{c}0.036 \\
{[0.583]}\end{array}$ & $\begin{array}{l}0.0405^{*} \\
{[0.000]}\end{array}$ \\
\hline D.NEET & - & $\begin{array}{c}0.200 \\
{[0.576]}\end{array}$ & $\begin{array}{c}0.200 \\
{[0.417]}\end{array}$ & $\begin{array}{c}0.218^{*} \\
{[0.000]}\end{array}$ \\
\hline D.UnemploymentTotal & - & $\begin{array}{l}-0.298 \\
{[0.282]}\end{array}$ & $\begin{array}{l}-0.298 \\
{[0.178]}\end{array}$ & $\begin{array}{l}-0.986^{*} \\
{[0.000]}\end{array}$ \\
\hline D. TertiaryEducationalAttainment & - & $\begin{array}{l}-0.201 \\
{[0.224]}\end{array}$ & $\begin{array}{l}-0.201 \\
{[0.221]}\end{array}$ & $\begin{array}{c}-0.193^{*} \\
{[0.000]}\end{array}$ \\
\hline D.AdultParticipationinLearning & - & $\begin{array}{c}0.214 \\
{[0.330]}\end{array}$ & $\begin{array}{c}0.214 \\
{[0.080]} \\
\end{array}$ & $\begin{array}{c}0.135^{*} \\
{[0.025]} \\
\end{array}$ \\
\hline constant & $\begin{array}{l}49.913 \\
{[0.000]} \\
\end{array}$ & $\begin{array}{l}-4.511 \\
{[0.540]}\end{array}$ & $\begin{array}{l}-4.511 \\
{[0.583]}\end{array}$ & $\begin{array}{c}6.405^{*} \\
{[0.000]} \\
\end{array}$ \\
\hline Hausman chi2 & -156.02 & 5.39 & - & - \\
\hline Wald chi2(df) & $\begin{array}{c}(7)=80.1 \\
{[0.0000]}\end{array}$ & $\begin{array}{c}(7)=61.64 \\
{[0.0000]}\end{array}$ & $\begin{array}{c}(7)=35.73 \\
{[0.0000]}\end{array}$ & $\begin{array}{c}(8)=76,249.88 \\
{[0.0000]}\end{array}$ \\
\hline Rho & 0.541 & 0.57985 & 0.57985 & \\
\hline $\mathrm{R}$ within & 0.391 & 0.1782 & 0.1782 & - \\
\hline $\mathrm{R}$ between & 0.4391 & 0.2928 & 0.2928 & - \\
\hline R overall & 0.3949 & 0.2442 & 0.2442 & - \\
\hline $\begin{array}{l}\text { Cross-sectional dependence } \\
\text { (Pesaran's test of cross sectional } \\
\text { independence) }\end{array}$ & $\begin{array}{c}0.806 \\
{[0.4202]}\end{array}$ & $\begin{array}{c}1.835 \\
{[0.0665]}\end{array}$ & $\begin{array}{c}1.835 \\
{[0.0665]}\end{array}$ & - \\
\hline \multicolumn{4}{|l|}{ Sargan test of overidentifying restrictions } & $\begin{array}{c}23.2152 \\
{[0.999]} \\
\end{array}$ \\
\hline \multirow{2}{*}{\multicolumn{4}{|c|}{ Arellano-Bond test for zero autocorrelation in first-differenced errors }} & $\begin{array}{c}\mathrm{AR}(1) \\
\mathrm{z}=-2.2773 \\
{[\mathbf{0 . 0 2 2 8}]}\end{array}$ \\
\hline & & & & $\begin{array}{c}\mathrm{AR}(2) \\
\mathrm{z}=-0.8026 \\
{[0.4222]}\end{array}$ \\
\hline
\end{tabular}

Note: P-value in box parentheses; ${ }^{*} \mathrm{P}$-value $<0.05$. 
Bond estimator includes the lagged values of endogenous variable and contains an internally transformation of the estimates using lagged differences and levels. To study the robustness of the estimates, the Sargan test of overidentifying restrictions and the Arellano-Bond test for zero autocorrelation were used. The Sargan test is used to verify the presence of endogeneity. By rejecting the null hypothesis of the test, the Sargan test shows that the instruments are not correctly specified, and the model needs to be reconsidered. The results show strong evidence to not reject the null hypothesis, so the model in this case is correctly specified. The Arellano-Bond test is another key postestimation test used to study the presence of serial correlation. Though for the AR (1) there is strong evidence of rejecting the null hypothesis of no serial correlation between the error, the model is not misspecified. This occurs due to the lagged estimation value of the endogenous variable. The model should be reconsidered only if the rejection of the null hypothesis occurs at higher orders of autocorrelation, which implies serial correlation and not valid moment conditions. For the second-order AR (2) serial correlation there is strong evidence of not rejecting the null hypothesis, so the residual term is not correlated in level (StataCorp, 2015). The results of the Sargan test and the ArellanoBond test are presented in Tab. 4.

The results of the dynamic GMM panel data model show that the crude rate of net migration in the current period is positively influenced by the crude rate of net migration in the previous period. If the crude rate of net migration increased in the previous period, the current rate of net migration increased, in average, by 0.573 units. The economic growth has a positive impact on the migration flows, which means that for countries with high GDP per capita there is also a positive net migration. Besides the GDP per capita, an increase by one unit in the employment rate of recent graduates, NEET and of the adult participation in learning, will also attract immigrants in a country. An interesting aspect regarding education is that if the level of tertiary education attainment will increase, there will be an increase of the emigration flow. This result is in line with the studies related to highly skilled migrants that highlighted the magnitude of a new migration phenomenon called brain drain (Boeri et al., 2012).
The estimated models serve to test the direction and influence of the SDG's as determinants of migration flows. Most coefficients keep the direction of the link between migration and the variables of interest in all stages of analysis. An interesting result to emphasize is in the case of Employment rate of recent graduates and Adult participation in learning. For these two exogenous variables, the estimates of the first stage are showing an indirect relationship, while for the estimates made in the other stages the estimate coefficients are showing a direct relationship. This changed results occur while the first difference operator was applied. This may show that a change in time of the Employment rate of recent graduates and Adult participation in learning will conduct to an immigration flow.

\section{Conclusions}

This paper explored the migration and sustainable development relationship through the perspective of education, labour market and economic growth. The importance of this study derived from the reversed perspectives analysis. As most authors considered migration as a factor that impacted upon SDG's, this paper developed four stages of analysis which analysed whether SDG's were determinants of migratory flows. The results confirmed a significant relationship between crude rate of net migration and the variables related to SDG 4 and SDG 8. Economic growth and education have been demonstrated to be pull factors for the migration, while labour market issues push factors.

One of the main limitations of the analysis was that most of the indicators used to measure the achievement of SDG's were relatively new. (United Nations General Assembly, 2017). Consequently, the dataset covered only a period of 11 years, from 2008 to 2018 .

Due to the COVID-19 crisis, the migration patterns will most probably suffer some changes, mainly because the pandemic has forced people to stay home. This crisis has led to a reshaping of the labour market, especially through the increasing of remote work (Fana et al., 2020). The same was true for education, as students and professors were forced to continue their activity from home. The migration and sustainable development nexus is highly important for policymakers. In the light of the recent COVID-19 related events, adaptive 
policies need to be created in order to cope with the new social situation.

\section{References}

Ahmad, M., \& Khan, R. E. A. (2019). Does demographic transition with human capital dynamics matter for economic growth? A dynamic panel data approach to GMM. Social Indicators Research, 142(2), 753-772. https://doi.org/10.1007/s11205-018-1928-x

Bali Swain, R., \& Yang-Wallentin, F. (2020). Achieving sustainable development goals: predicaments and strategies. International Journal of Sustainable Development \& World Ecology, 27(2), 96-106, https://doi.org/10.1080 /13504509.2019.1692316

Baltagi, B. H., Kao, C., \& Peng, B. (2016). Testing cross-sectional correlation in large panel data models with serial correlation. Econometrics, 4(4), 44. https://doi.org/10.3390/ econometrics 4040044

Baum, C. F., \& Christopher, F. (2006). An introduction to modern econometrics using Stata. College Station, TX: Stata press.

Baum, C. F. (2014). Dynamic Panel Data estimators, EC 823: Applied Econometrics. Chestnut Hill, MA: Boston College. Retrieved from https://fmwww.bc.edu/EC-C/S2014/823/ EC823.S2014.nn05.slides.pdf

Boeri, T., Brücker, H., \& Docquier, F. (2012). Brain drain and brain gain: The global competition to attract high-skilled migrants. Oxford: Oxford University Press.

Death, C. \& Gabay, C., (2015). Doing biopolitics differently? Radical potential in the post-2015 MDG and SDG debates. Globalizations, 12(4), 597-612. https://doi.org/ 10.1080/14747731.2015.1033172

de Haas, H. (2011). The determinants of international migration: Conceptualising policy, origin and destination effects (Working paper no. 2, DEMIG project paper 2). Siegen: DEMIG.

Etzo, I. (2011). The determinants of the recent interregional migration flows in Italy: A panel data analysis. Journal of Regional Science, 51(5), 948-966. https://doi. org/10.1111/j.1467-9787.2011.00730.x

Fana, M., Torrejón Pérez, S., \& FernándezMacías, E. (2020). Employment impact of Covid-19 crisis: from short term effects to long terms prospects. Journal of Industrial and Business Economics, 47, 391-410. https://doi. org/10.1007/s40812-020-00168-5
Faist, T. (2011). The Volume and Dynamics of International Migration and Transnational Social Spaces, Chapter 2: A Review of Dominant Theories of International Migration. Oxford: Oxford University Press, Scholarship Online.

Fehling, M., Nelson, B. D., \& Venkatapuram, S. (2013). Limitations of the Millennium Development Goals: a literature review. Global Public Health, 8(10), 1109-1122. https://doi.org /10.1080/17441692.2013.845676

Franc, S., Časni, A. Č., \& Barišić, A. (2019). Determinants of migration following the EU enlargement: a panel data analysis. South East European Journal of Economics and Business, 14(2), 13-22. https://doi.org/10.2478/jeb-2019-0010

Global Forum on Migration and Development. (2017). Migration Governance Framework (MiGOF). Retrieved August 1, 2020, from https://gfmd.org/pfp/ppd/5694

Ha, W., Yi, J., Yuan, Y., \& Zhang, J. (2016). The dynamic effect of rural-to-urban migration on inequality in source villages: System GMM estimates from rural China. China Economic Review, 37, 27-39. https://doi.org/10.1016/j. chieco.2015.09.002

Harris, R. D. F., \& Tzavalis, E. (1999). Inference for unit roots in dynamic panels where the time dimension is fixed. Journal of Econometrics, 91(2), 201-226. https://doi. org/10.1016/S0304-4076(98)00076-1

Hausman, J. A., \& Pinkovskiy, M. (2017). Estimating dynamic panel models: backing out the Nickell Bias (Cemmap Working Paper CWP53/17). London: The Institute for Fiscal Studies, Department of Economics, UCL. https://doi.org/10.1920/wp.cem.2017.5317

Holliday, J., Hennebry, J., \& Gammage, S. (2019). Achieving the sustainable development goals: surfacing the role for a gender analytic of migration. Journal of Ethnic and Migration Studies, 45(14), 2551-2565. https://doi.org/10 .1080/1369183X.2018.1456720

Hulme, D. (2009). The Millennium Development Goals (MDGs): A Short History of the World's Biggest Promise (BWPI Working Paper No. 100). Manchester: The University of Manchester, GDI. https://doi.org/10.2139/ ssrn. 1544271

International Labour Organization (ILO). (2015). ILO Global Estimates on Migrant Workers: Results and Methodology - Special Focus on Migrant Domestic Workers. Geneva: International Labour Office. 
International Organization for Migration. (2018). Migration and the 2030 Agenda: A Guide for Practitioners. Geneva: International Organization for Migration. Retrieved from https://publications.iom.int/books/migrationand-2030-agenda-guide-practitioners

International Organization for Migration. (2019). Migration governance indicators. A global perspective. Geneva: International Organization for Migration. Retrieved from https://publications.iom.int/books/migrationgovernance-indicators-global-perspective

Kumar, S., Kumar, N., \& Vivekadhish, S. (2016). Millennium Development Goals (MDGs) to Sustainable Development Goals (SDGs): Addressing Unfinished Agenda and Strengthening Sustainable Development and Partnership. Indian Journal of Community Medicine, 41(1), 1-4. https://doi. org/10.4103/0970-0218.170955

Long, K., Vidal, E. S., Kuch, A., \& HagenZanker, J. (2017). Citizenship, migration and the 2030 Agenda for Sustainable Development (Briefing Series). London: ODI, Bern: Swiss Agency for Development and Cooperation (SDC). Retrieved from https://www.odi.org/sites/ odi.org.uk/files/resource-documents/11744.pdf

Mallett, R. (2018). Decent work, migration and the 2030 agenda for sustainable development (Briefing Series). Bern: Swiss Agency for Development and Cooperation.

Mayda, A. M. (2010). International migration: A panel data analysis of the determinants of bilateral flows. Journal of Population Economics, 23(4), 1249-1274. https://doi.org/10.1007/s00148-009-0251-x

McGregor, E. (2020). Migration, the MDGs, and SDGs: Context and Complexity. In T. Bastia \& R. Skeldon (Eds.), Routledge Handbook of Migration and Development. London: Routledge.

Migration Data Portal. (2020).

https://migrationdataportal.org/

Napolitano, O., \& Bonasia, M. (2010). Determinants of different internal migration trends: The Italian experience. The Manchester School, 80(4), 525-544. https://doi.org/10.1111/ j.1467-9957.2012.02300.x

Nicolai, S., Wales, J., \& Aiazzi, E. (2016). Education, migration and the 2030 Agenda for Sustainable Development (Briefing Series). London: ODI, Bern: Swiss Agency for Development and Cooperation (SDC). Retrieved from https://www.odi.org/sites/odi. org.uk/files/resource-documents/12422.pdf
Nyberg-Sørensen, N., Hear, N. V., \& Engberg-Pedersen, P. (2002). The Migration-Development Nexus Evidence and Policy Options State-of-the-Art Overview. International Migration, 40(5), 3-47. https://doi. org/10.1111/1468-2435.00210

O'Reilly, K. (2013). International migration and social theory. In The encyclopedia of global human migration. Wiley Online Library. https:// doi.org/10.1002/9781444351071.wbeghm307

Overseas Development Institute. (2017). Migration and the 2030 Agenda for Sustainable Development (Briefing Series). London: ODI, Bern: Swiss Agency for Development and Cooperation (SDC). Retrieved from https://www.odi.org/sites/odi.org.uk/files/ resource-documents/12422.pdf

Parkins, N. C. (2011). Push and pull factors of migration. American Review of Political Economy, 8(2), 6-24.

Piper, N. (2017). Migration and the SDGs. Global Social Policy, 17(2), 231-238. https:// doi.org/10.1177/1468018117703443

Roodman, D. (2009). How to do Xtabond2: An Introduction to Difference and System GMM in Stata. The Stata Journal, 9(1), 86-136. https://doi.org/10.1177/1536867X0900900106

Sitarz, D. (1993). Agenda 21: The Earth summit strategy to save our planet. Tucson, AZ: Earth Press. Retrieved from https://www.osti. gov/biblio/6289330

Skeldon, R. (2008). Migration and Development. Paper presented on the United Nations Expert Group Meeting on International Migration and Development in Asia and the Pacific. September 20-21, 2008, Bangkok, Thailand. Retrieved from https://www.un.org/ development/desa/pd/sites/www.un.org. development.desa.pd/files/unpd_egm_200809_ paper_skeldon_mig_and_dev.pdf

Skeldon, R. (2014). Migration and Development: A global perspective. New York, NY: Routledge.

Soylu, Ö. B., Çakmak, I., \& Okur, F. (2018). Economic growth and unemployment issue: Panel data analysis in Eastern European Countries. Journal of International Studies, 11(1), 93-107. https://doi.org/10.14254/20718330.2018/11-1/7

StataCorp. (2013). Stata glossary and index. Retrieved July 27, 2020, from https://www.stata.com/manuals13/xtxtunitroot.pdf

StataCorp. (2015). Stata treatment-effects reference manual. College Station, TX: Stata Press Publication. 
Teixeira, A. A. C., \& Queirós, A. S. S. (2016). Economic growth, human capital and structural change: A dynamic panel data analysis. Research policy, 45(8), 1636-1648. https://doi. org/10.1016/j.respol.2016.04.006

Torres-Reyna, O. (2007). Panel data analysis fixed and random effects using Stata (v. 4.2) (Presentation 112). Princeton, NJ: Priceton University, Data \& Statistical Services.

Ullah, S., Akhtar, P., \& Zaefarian, G. (2018). Dealing with endogeneity bias: The generalized method of moments (GMM) for panel data. Industrial Marketing Management, 71, 69-78. https://doi.org/10.1016/j. indmarman.2017.11.010

United Nations. (1993). Report of the United Nations Conference on Environment and Development, Rio de Janeiro, June 3-14, 1992. New York, NY: United Nations.
United Nations. (2005). Millennium Project. Investing in development: A practical plan to achieve the Millennium Development Goals. New York, NY: United Nations.

United Nations General Assembly. (2017). Global indicator framework for the Sustainable Development Goals and targets of the 2030 Agenda for Sustainable Development. Retrieved from https://www.howandwhentoreference.com/

Usher, E. (2005). The millennium development goals and migration. Geneva: International Organization for Migration.

Wickramasinghe, A. A. I. N., \& Wimalaratana, W. (2016). International migration and migration theories. Social Affairs, 1(5), 13-32. https://doaj. org/article/90df97f1572447a7b64dccff72c43429

Wooldridge, J. M. (2010). Econometric analysis of cross section and panel data. Cambridge, MA: MIT Press. 


\section{Appendix}

\section{Tab. 1A: Descriptive statistics}

\begin{tabular}{|c|c|c|c|c|c|c|}
\hline \multicolumn{2}{|l|}{ Variable } & Mean & Std. Dev. & Min & Max & Obs. \\
\hline \multirow{3}{*}{ CrudeRateofNetMigration } & overall & 2.184091 & 6.89755 & -25.2 & 35.3 & $N=308$ \\
\hline & between & & 5.499326 & -9.00909 & 17.36364 & $\mathrm{n}=28$ \\
\hline & within & & 4.280036 & -21.4432 & 22.08409 & $\mathrm{~T}=11$ \\
\hline \multirow{3}{*}{ GDPpercapita } & overall & 99.87013 & 42.214 & 43 & 272 & $N=308$ \\
\hline & between & & 42.43517 & 46.81818 & 265.5455 & $\mathrm{n}=28$ \\
\hline & within & & 6.319403 & 78.41558 & 139.4156 & $T=11$ \\
\hline \multirow{3}{*}{ NEET } & overall & 13.44513 & 5.146898 & 4.3 & 27.2 & $N=308$ \\
\hline & between & & 4.8071 & 4.972727 & 22.33636 & $\mathrm{n}=28$ \\
\hline & within & & 2.033485 & 6.317857 & 19.61786 & $\mathrm{~T}=11$ \\
\hline \multirow{3}{*}{ UnemploymentTotal } & overall & 9.272403 & 4.642873 & 2.3 & 27.7 & $N=308$ \\
\hline & between & & 3.832444 & 5.227273 & 20.1 & $\mathrm{n}=28$ \\
\hline & within & & 2.710547 & -2.6276 & 17.24513 & $T=11$ \\
\hline \multirow{3}{*}{ TertiaryEducationalAttainment } & overall & 37.7211 & 10.18353 & 15.4 & 58.7 & $N=308$ \\
\hline & between & & 9.349624 & 22.1 & 52.75455 & $\mathrm{n}=28$ \\
\hline & within & & 4.374489 & 26.41201 & 49.23019 & $\mathrm{~T}=11$ \\
\hline \multirow{3}{*}{ GINIcoeff } & overall & 29.95974 & 3.79245 & 20.9 & 40.2 & $N=308$ \\
\hline & between & & 3.689625 & 23.89091 & 36.03636 & $\mathrm{n}=28$ \\
\hline & within & & 1.101258 & 26.37792 & 34.12338 & $\mathrm{~T}=11$ \\
\hline \multirow{3}{*}{$\begin{array}{l}\text { EmploymentRatesofFecent } \\
\text { Graduates }\end{array}$} & overall & 77.66104 & 10.29625 & 40 & 96.2 & $N=308$ \\
\hline & between & & 9.361923 & 51.95455 & 93.76364 & $\mathrm{n}=28$ \\
\hline & within & & 4.606733 & 64.46104 & 94.00649 & $\mathrm{~T}=11$ \\
\hline \multirow{3}{*}{ AdultParticipationinLearning } & overall & 10.47403 & 7.605894 & 0.9 & 32.7 & $N=308$ \\
\hline & between & & 7.480963 & 1.454545 & 30.10909 & $\mathrm{n}=28$ \\
\hline & within & & 1.925556 & 2.846753 & 16.98312 & $T=11$ \\
\hline
\end{tabular}

